
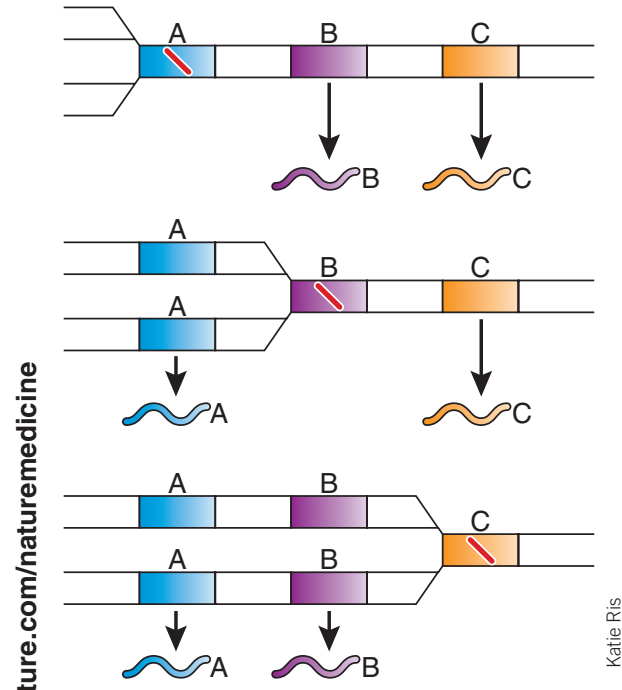

Figure 2 The walking dead. Psoralen-treated $\triangle u v r A B$ Listeria are unable to replicate their chromosomes beyond the point of a random crosslink introduced by the treatment. Because of the replication block, septation and cell division are also blocked. Nevertheless, undamaged genes continue to be expressed properly. The culture as a whole expresses all genes, including any necessary to induce an immune response.

tured cells infected with the damaged $\triangle u v r A B$ bacteria express Listeria-coded peptides on their surface and could activate CD8 T cells in vitro, whereas equally attenuated nonmutant bacteria were ineffective.

But could these psoralen-treated $\triangle u v r A B$ bacteria elicit an immune response in vivo? The authors show that recombinant vaccine carrying the gene encoding ovalbumin could protect mice from viral infection by vaccinia virus that carried the same gene. They also found that immunization with a single booster injection was as effective as the live vaccine at protecting mice from infection with wild-type virulent Listeria. To test their approach in a tumor-vaccine model, the authors generated Listeria expressing a tumor antigen. Mice implanted with CT26 tumor cells develop lung nodules 20 days after implant and usually die. But, impressively, mice vaccinated on three consecutive days, starting shortly after tumor cell infusion, were protected against nodule formation and death. Protection was accompanied by the appearance in vivo of epitope-specific cytolytic CD8 T cells.

Will the approach be of general use? Brockstedt et al. ${ }^{1}$ have created a protocol that may be applicable to a wide range of organisms-indeed, they show that they can 'kill' Bacillus anthracis using the same approach. Their organisms really are dead, yet they retain full metabolic activity and express the cellular functions, except replication, to induce protective immunity. The strategy seems promising, but a crucial question will be whether the efficacy seen in these mouse studies can translate to primates. It is known that at least 24 hours of antigen presentation is necessary to achieve a full immune response ${ }^{7}$. But, unable to replicate, these organisms probably are destroyed within hours by polymorphonuclear leukocytes of the innate immune system. This may explain why after immunization with the ovalbumin-expressing vaccine the authors found somewhat weaker CD8 responses compared to the live vaccine.

The recognition of Listeria as a valuable vaccine vector has resulted in a plethora of attenuation models, beginning with $\triangle$ act $A$ bacteria (blocked in intercellular spread) ${ }^{6,8,9}$, conditionally lethal $\Delta$ dal $\Delta$ dat Listeria (blocked in cell wall synthesis) that are unable to multiply unless supplied transiently with Dalanine $\mathrm{e}^{10-12}$ and metabolic mutants ${ }^{13}$. As vaccinology is unfortunately still based primarily on empiric observation, these various approaches can only be compared in head-tohead studies. But this new protocol may have a leg up on the others as a cancer vaccine in an arena which Listeria has already shown considerable promise ${ }^{14}$ and in which safety is of utmost importance.

1. Brockstedt, D.G. et al. Nat. Med. 11, 853-860 (2005).

2. Mackaness, G.B. J. Exp. Med. 116, 381-406 (1962).

3. Schafer, R., Portnoy, D.A., Brassell, S.A. \& Paterson, Y. J. Immunol. 149, 53-59 (1992).

4. Frankel, F.R., Hedge, S., Lieberman, J. \& Paterson, Y. J. Immunol. 155, 4775-4782 (1995).

5. Shen, H. et al. Proc. Natl. Acad. Sci. USA 92, 3987-3991 (1995).

6. Goossens, P.L., Milon, G., Cossart, P. \& Saron, M.-F. Int. Immunol. 7, 797-802 (1995).

7. Mercado, R. et al. J. Immunol. 165, 6833-6839 (2000).

8. Brockstedt, D.G. et al. Proc. Natl. Acad. Sci. USA 101, 13832-13837 (2004).

9. Angelakopoulos, H. et al. Infect. Immun. 70, 35923601 (2002).

10. Thompson, R.J., Bouwer, H.G.A., Portnoy, D.A. \& Frankel, F.R. Infect. Immun. 66, 3552-3561 (1998).

11. Li, Z., Zhao, X., Higgins, D.E. \& Frankel, F.R. Infect. Immun. (in the press).

12. Zhao, X., Li, Z., Gu, B. \& Frankel, F.R. Infect. Immun. (in the press).

13. Stritzker, J. et al. Infect. Immun. 72, 5622-5629 (2004).

14. Pan, Z.-K., Ikonomidis, G., Pardoll, D. \& Paterson, Y. Cancer Res. 55, 4776-4779 (1995).

\title{
Growing older, growing apart
}

Monozygotic twins originate from a single fertilized egg, but they are not truly 'identical'-for instance, they can develop different chronic diseases. But are the differences due to nature-subtle sequence changes in the DNA - or nurture? In a recent issue of the Proceedings of the National Academy of Sciences, Mario Fraga et al. take an alternate approach to this debate, implicating epigenetic alterations in the differences (doi:10.1073/pnas.0500398102).

Fraga et al. analyzed DNA methylation and histone acetylation in lymphocytes of 80 twins. They found significant differences in these epigenetic modifications between siblings in $35 \%$ of the twin pairs - and the differences increased with age. To show this, they generated labeled PCR probes for each individual that reflected the distribution of methyl groups along their DNA, and hybridized these to chromosomes. Shown are the DNA methylation patterns of chromosome 1 from 3-year-old twins (left pair) and 50-year-old twins (right pair). The younger twins showed similar patterns of methylation, visualized as an overlap of green and red probes (yellow). The chromosomes from the older twins show substantial disparity in methylation patterns (distinct red and green pattern).

Do such epigenetic differences lead to variations in gene expression that might explain phenotypic differences between monozygotic twins? In this study, the answer was yesgene expression patterns in the 3-year-old twins were virtually identical, but varied widely in the 50-year-old twins. So fear not, identical twin, you are unique. 